\title{
PEMODELAN JUMLAH KASUS PNEUMONIA BALITA DI JAWA TIMUR MENGGUNAKAN REGRESI SPATIAL AUTOREGRESSIVE MOVING AVERAGE
}

\author{
Made Narymurti Widyastuti ${ }^{1 \S}$, I Gusti Ayu Made Srinadi ${ }^{2}$, Made Susilawati ${ }^{3}$ \\ ${ }^{1}$ Program Studi Matematika, Fakultas MIPA - Universitas Udayana [Email: nary.widyastuti@ gmail.com] \\ ${ }^{2}$ Program Studi Matematika, Fakultas MIPA - Universitas Udayana [Email: srinadi@unud.ac.id] \\ ${ }^{3}$ Program Studi Matematika, Fakultas MIPA - Universitas Udayana [Email: susilawati.made@gmail.com] \\ ${ }^{\S}$ Corresponding Author
}

\begin{abstract}
The purpose of this study is to model and determine the factors that significantly influence the number of toddler pneumonia cases in East Java Province. Modeling the number of toddler pneumonia cases was conducted using spatial autoregressive moving average (SARMA) regression analysis. The results showed that the best model to modeling was SARMA (1.1) with the AIC value is 649,55 and the coefficient of determination $\left(R^{2}\right)$ is $73,17 \%$. The significant factors that affect the number of these cases are the number of toddler receiving complete basic immunization and the number of toddler receiving health services in each district/city.
\end{abstract}

Keywords: Regression, SARMA, toddlers Pneumonia case

\section{PENDAHULUAN}

Analisis regresi spasial adalah metode statistika untuk data yang memiliki pengaruh lokasi atau daerah. Analisis terhadap data seperti ini memerlukan perhatian khusus karena kondisi dari suatu lokasi pengamatan berbeda dengan lokasi pengamatan lain. Meskipun demikian, sesuai dengan hukum pertama geografis yang dikemukakan oleh Tobler kondisi di suatu lokasi pengamatan memiliki hubungan yang erat dengan lokasi pengamatan lain yang berdekatan (Anselin, 1988).

Pemodelan spasial dapat dibedakan menjadi dua yaitu pemodelan dengan tipe data berdasarkan pendekatan titik dan tipe data berdasarkan pendekatan area. Selain itu, dikembangkan analisis spasial dengan pengaruh spasial pada tingkat yang lebih tinggi yaitu spatial autoregressive moving average (SARMA). Model SARMA memiliki struktur yang dibangun melalui model deret waktu ARMA. Dalam model SARMA terdapat matriks pembobot spasial sebagai pengganti pengaruh waktu pada model deret waktu ARMA. Menurut Kruk (2002) kelebihan dari model ini adalah parameter model spasial dapat diestimasi untuk hubungan spasial pada tingkatan yang lebih tinggi.
Di Provinsi Jawa Timur pneumonia pada balita masih menjadi masalah kesehatan yang cukup besar. Pada tahun 2017 kasus pneumonia di Provinsi Jawa Timur mencapai 86.358 balita penderita ditemukan dan ditangani. Walaupun jumlah ini menurun dari tahun sebelumnya (tahun 2016 mencapai 102.712), kasus pneumonia balita di Provinsi Jawa Timur masih tinggi.

Tingginya jumlah kasus pneumonia balita ini berdampak buruk bagi kualitas kesehatan. Oleh karena itu, untuk menanggulangi hal ini dilakukan analisis guna meminimalkan jumlah kasus tersebut. Penularan penyakit serta peningkatan frekuensi infeksi pneumonia balita menurut Qaulyiah (2010) dipengaruhi oleh letak geografis. Oleh karena itu analisis dilakukan dengan analisis regresi SARMA untuk memodelkan kasus pneumonia pada setiap kabupaten/kota di Provinsi Jawa Timur. Tujuan dari penelitian ini adalah untuk memodelkan jumlah kasus pneumonia di setiap kabupaten/kota di Provinsi Jawa Timur serta untuk mengetahui faktor yang secara signifikan berpengaruh terhadap jumlah kasus pneumonia balita di Provinsi Jawa Timur. 


\section{METODE PENELITIAN}

Data pada penelitian ini berupa data sekunder yang diperoleh dari Profil Kesehatan Dinas Kesehatan Provinsi Jawa Timur. Unit observasi (amatan) penelitian ini adalah data profil kesehatan pada 38 kabupaten/kota di Provinsi Jawa Timur pada tahun 2017. Varibel dependen penelitian ini adalah jumlah kasus pneumonia balita di setiap kabupaten/kota di Provinsi Jawa Timur $(Y)$.Variabel independen terdiri dari jumlah balita yang mendapat ASI eksklusif $\left(X_{1}\right)$, jumlah balita yang mendapat imunisasi dasar lengkap $\left(X_{2}\right)$, jumlah balita yang mendapatkan pelayanan kesehatan $\left(X_{3}\right)$, jumlah rumah tangga ber-PHBS $\left(X_{4}\right)$, dan jumlah penduduk miskin $\left(X_{5}\right)$ di setiap kabupaten/kota di Provinsi Jawa Timur.

Metode analisis yang digunakan pada penelitian ini adalah analisis regresi spasial autoregresive moving average (SARMA), dengan tahapan analisis sebagai berikut:

1. Estimasi Model Regresi Linier dan Uji Asumsi Regresi Linier

Analisis regresi merupakan metode statistika yang memanfaatkan hubungan antar dua variabel sehingga salah satunya dapat diramalkan dari variabel lainnya. Model umum dari analisis regresi dapat dinyatakan sebagai berikut (Kutner, et al., 2005).

$$
\begin{gathered}
Y_{i}=\beta_{0}+\beta_{1} X_{i, 1}+\cdots+\beta_{k-1} X_{i, k-1}+\varepsilon_{i} .(1) \\
\text { Model regresi linier sederhana yang }
\end{gathered}
$$
merupakan landasan dari banyak teori ekonometrika memiliki beberapa asumsi (Gujarati \& Porter, 2009), diantaranya yaitu:

a. Varians dari galat adalah konstan atau homoskedastisitas.

Menurut Gujarati \& Porter (2009), salah satu uji formal yang dapat dilakukan untuk mengidentifikasi homokedastisitas adalah uji Bruesch-Pagan. Hipotesis dari uji ini adalah sebagai berikut:

$H_{0}$ : Ragam homogen

$H_{1}$ : Ragam tidak homogen

Keputusan penolakan $H_{0}$ adalah ketika nilai $B P>\chi_{\alpha,(K-1)^{2}}^{2}$.

b. Tidak terdapat autokorelasi antarsisaan.

Mengidentifikasi adanya autokorelasi dapat dilakukan dengan uji DurbinWatson.

Hipotesis dari uji ini adalah sebagai berikut:

$H_{0}$ : Tidak terdapat autokorelasi

$H_{1}$ : Terdapat autokorelasi
Nilai statistik uji Durbin-Watson (d) dibandingkan dengan nilai $d L$ dan $d U$ pada tabel Durbin-Watson. Daerah kritis didefinisikan sebagai berikut:

- jika $d<d L$ maka $H_{0}$ ditolak yang artinya terdapat autokorelasi;

- jika $d>d U$ maka $H_{0}$ tidak dapat ditolak yang artinya tidak terdapat autokorelasi;

- jika $d L \leq d \leq d U$ maka pengujian tidak meyakinkan.

c. Tidak terdapat multikolinieritas, artinya tidak terdapat hubungan linier yang sempurna antar variabel bebas.

Multikolinieritas pada suatu model regresi linier diidentifikasi dengan menghitung nilai variance-inflating factor (VIF). Nilai $V I F$ yang kurang dari lima menunjukkan bahwa tidak terdapat multikolinieritas pada model.

d. Sisaan dari model yang diestimasi berdistribusi normal.

Kenormalan sisaan dari suatu model dapat diketahui dengan melakukan uji JarqueBera. Hipotesis dari uji ini adalah sebagai berikut:

$H_{0}$ : Sisaan mengikuti sebaran normal

$H_{1}$ : Sisaan tidak mengikuti sebaran normal

Uji Jarque-Bera mempunyai distribusi chisquare dengan derajat bebas 2. Jika $J B>\chi_{2}^{2}$ maka $H_{0}$ ditolak yang artinya sisaan dari model tidak berdistribusi normal.

2. Uji Kebergantungan Spasial

Regresi spasial merupakan metode statistika yang digunakan untuk menganalisis hubungan antara variabel dependen dan independen dengan mempertimbangkan pengaruh antar daerah. Model regresi spasial secara umum dapat dinyatakan sebagai berikut (Anselin, 1988).

$$
y=\phi W_{1} y+X \beta+\theta W_{2} \varepsilon+\mu .
$$

Matriks $W_{1}$ sama dengan $W_{2}$ yang sering disebut matriks pembobot spasial $(W)$. Matriks ini berupa matriks simetris berukuran $n \times n$ yang menunjukan hubungan kedekatan antar wilayah. Struktur yang mendasari hubungan kedekatan antar wilayah adalah bahwa jika dua daerah yang memiliki batas umum dengan panjang tidak-nol, daerah ini dianggap berdekatan dan nilai bobotnya adalah satu, jika tidak makan nilai bobotnya adalah nol. 
Terdapat pengembangan regresi spasial pada tingkat yang lebih tinggi yaitu spatial autoregressive moving average (SARMA). SARMA merupakan analisis spasial yang mengasumsikan bahwa terdapat pengaruh spasial pada variabel dependen dan sisaan. Model SARMA merupakan analogi spasial dari kelas model deret waktu ARMA yang dengan matriks pembobot spasial sebagai pengganti faktor waktu dalam model deret waktu ARMA. Model SARMA dikembangkan menjadi model regresi SARMA yang ditandai dengan penambahan variabel independen pada model SARMA. Model regresi SARMA secara umum adalah sebagai berikut:

$$
\begin{aligned}
y_{i}=\beta_{0}+\phi_{1} \sum_{j=1}^{n} w_{i, j} y_{j}+\cdots+\phi_{p} \sum_{j=1}^{n} w_{i, j}^{p} y_{j} \\
+\beta_{1} X_{1, i}+\cdots+\beta_{k-1} X_{k-1, i} \\
+\theta_{1} \sum_{j=1}^{n} w_{i, j} \varepsilon_{j}+\cdots \\
+\theta_{q} \sum_{j=1}^{n} w_{i, j}^{p} \varepsilon_{j}+\varepsilon_{i} .
\end{aligned}
$$

Bila dinotasikan dengan matriks, Persamaan (3) dapat dinyatakan sebagai berikut.

$$
\left(I-\sum_{i=1}^{p} \phi_{i} W^{i}\right) y=X \beta+\left(I+\sum_{i=1}^{q} \theta_{i} W^{i}\right) \varepsilon .
$$

Matriks $W$ merupakan matriks simetris, sehingga dapat didiagonalisasi. Oleh karena itu dapat dibentuk matriks orthogonal $U$ dan $V$ yang memenuhi $W=U \Lambda V$, dengan $\mathrm{V}=\mathrm{U}^{\mathrm{T}}=$ $\mathrm{U}^{-1}, \Lambda$ menyatakan $\operatorname{diag}\left(\lambda_{1}, \lambda_{2}, \ldots, \lambda_{n}\right)$ dan $\lambda_{n}$ merupakan nilai eigen dari matriks $W$. Berdasarkan hal tersebut, Persamaan (4) dapat dinyatakan sebagai berikut:

$U\left(I-\sum_{i=1}^{p} \phi_{i} \Lambda^{i}\right) V y=X \beta+U\left(I+\sum_{i=1}^{q} \theta_{i} \Lambda^{i}\right) V \varepsilon$.

misalkan:

$$
\begin{aligned}
& \Omega_{1}=\left(I-\sum_{i=1}^{p} \phi_{i} \Lambda^{i}\right), \\
& \Omega_{2}=\left(I+\sum_{i=1}^{q} \theta_{i} \Lambda^{i}\right), \\
& \mathrm{A}=\mathrm{U} \Omega_{1} V, \\
& \mathrm{~B}=\mathrm{U} \Omega_{2} V .
\end{aligned}
$$

Sehingga Persamaan (5) dapat dinyatakan sebagai berikut:

$$
\begin{aligned}
A y & =X \beta+B \varepsilon \\
\varepsilon & =B^{-1}(A y-X \beta) .
\end{aligned}
$$

$\varepsilon$ berdistribusi normal, sehingga dapat dibentuk fungsi densitas peluang sebagai berikut:

$f\left(\varepsilon_{i}\right)=\frac{1}{\sqrt{2 \pi \sigma^{2}}} \exp \left[-\frac{1}{2 \sigma^{2}}\left(\varepsilon_{i}^{2}\right)\right]$.

Fungsi likelihood dari fungsi densitas peluang pada Persamaan (7) adalah sebagai berikut:

$L\left(\varepsilon_{i}, \sigma^{2}\right)=\left(\frac{1}{2 \pi \sigma^{2}}\right)^{\frac{n}{2}} \exp \left\{-\frac{1}{2 \sigma^{2}}\left(\varepsilon^{T} \varepsilon\right)\right\}$.

Logaritma natural dari Persamaan (8) adalah sebagai berikut:

$$
\begin{aligned}
\ln (L)=-\frac{n}{2} \ln (2 \pi)-\frac{n}{2} \ln \left(\sigma^{2}\right)+\ln \left|B^{-1} A\right| & \\
+ & {\left[-\frac{1}{2 \sigma^{2}}\left(B^{-1}(A y\right.\right.} \\
& \left.-X \beta))^{T} B^{-1}(A y-X \beta)\right] .
\end{aligned}
$$

diperhatikan bahwa

$$
\begin{aligned}
\ln \left|B^{-1} A\right| & =\ln \left(\left|\mathrm{U} \Omega_{2}^{-1} V \mathrm{U} \Omega_{1} V\right|\right) \\
= & \ln \left(|U|\left|\Omega_{2}^{-1} \Omega_{1}\right||V|\right) \\
= & \ln \left(|U|\left|\Omega_{2}^{-1} \Omega_{1}\right|\left|\frac{1}{U}\right|\right) \\
= & \ln \left|\Omega_{2}^{-1} \Omega_{1}\right| \\
= & \ln \mid\left(I+\sum_{i=1}^{q} \theta_{i} \Lambda^{i}\right)^{-1}(I \\
& \left.\quad-\sum_{i=1}^{p} \phi_{i} \Lambda^{i}\right) \mid \\
= & \sum_{i=1}^{n} \ln \frac{\left(1-\sum_{j=1}^{p} \phi_{j} \lambda_{i}^{j}\right)}{\left(1+\sum_{j=1}^{q} \theta_{j} \lambda_{i}^{j}\right)} .
\end{aligned}
$$

Dengan mensubstitusikan Persamaan (10) ke Persamaan (9), diperoleh fungsi logaritma natural (In) likelihood sebagai berikut:

$$
\begin{aligned}
& \begin{aligned}
\ln (L)=-\frac{n}{2} \operatorname{In}(2 \pi) & -\frac{n}{2} \operatorname{In}\left(\sigma^{2}\right)+\sum_{i=1}^{n} \operatorname{In}\left(g_{i}\right) \\
+ & {\left[-\frac{1}{2 \sigma^{2}}\left(B^{-1}(A y\right.\right.} \\
& \left.-X \beta))^{T} B^{-1}(A y-X \beta)\right] . \quad \text { (11) }
\end{aligned} \\
& \text { dengan } g_{i}=\frac{\left(1-\sum_{j=1}^{p} \phi_{j} \lambda_{i}^{j}\right)}{\left(1+\sum_{j=1}^{q} \theta_{j} \lambda_{i}^{j}\right)} \text { dan } \Omega_{2}^{-1} \Omega_{1}= \\
& \operatorname{diag}\left(g_{1}, g_{2}, \ldots, g_{n}\right) .
\end{aligned}
$$

Penduga parameter model regresi SARMA terdiri dari:

a. Penduga Parameter $\beta$

Pendugaan parameter $\beta$ diperoleh dengan menurunkan fungsi ln likelihood pada Persamaan (10) secara parsial terhadap $\beta$ dan menyatakannya dengan nol. Penduga parameternya adalah sebagai berikut: 


$$
\hat{\beta}=\left(X^{T}\left(\hat{B} \hat{B}^{T}\right)^{-1} X\right)^{-1} X^{T}\left(\hat{B} \hat{B}^{T}\right)^{-1} \hat{A} y
$$

b. Penduga Parameter $\sigma^{2}$

Pendugaan parameter $\sigma^{2}$ diperoleh dengan menurunkan fungsi ln likelihood pada Persamaan (11) secara parsial terhadap $\sigma^{2}$ dan menyatakannya dengan nol, sehingga diperoleh penduga parameternya sebagai berikut:

$$
\hat{\sigma}^{2}=\frac{1}{n}(\hat{A} y)^{T} M \hat{A} y
$$

c. Penduga Parameter $\phi$ dan $\theta$

Pendugaan parameter $\phi$ dan $\theta$ tidak dapat dilakukan dengan dilakukan dengan menurunkan fungsi ln likelihood (metode maximum likelihood estimator) (Huang, 1984). Oleh karena itu diperlukan metode iterasi dalam menduga parameternya. Metode iterasi yang digunakan adalah iterasi numerik Davidon-Fletcher-Powell.

Adanya kebergantungan spasial pada data dapat diketahui dengan melakukan uji Lagrange Multiplier (LM). Terdapat tiga jenis uji Lagrange Multiplier (LM), antara lain:

a. uji kebergantungan spasial pada variabel dependen;

b. uji kebergantungan spasial pada sisaan;

c. uji kebergantungan spasial pada variabel dependen dan sisaan.

3. Pemodelan regresi spatial autoregressive moving average (SARMA)

Setelah itu, data yang memiliki kebergantungan spasial pada variabel dependen dan sisaan dianalisis dengan analisis regresi (SARMA). Pertama dilakukan penentuan model SARMA dengan fungsi autokorelasi spasial, selanjutnya menduga parameter model regresi SARMA yang diidentifikasi, memilih model terbaik dari model yang diidentifikasi dengan kriteria nilai AIC, melakukan uji signifikansi pada parameter model yang terpilih, dan terakhir interpretasi pada model terbaik.

\section{HASIL DAN PEMBAHASAN}

\section{Deskripsi Jumlah Kasus Pneumonia Balita di Provinsi Jawa Timur serta Faktor yang Memengaruhinya}

Angka yang menunjukkan banyaknya kasus dari setiap variabel dalam penelitian ini tampilkan dalam peta tematik (terlampir), hal ini bertujuan untuk mengetahui penyebaran data dari setiap variabel dari sudut kewilayahan. Dalam peta tematik banyaknya kasus dari setiap variabel dikelompokan menjadi lima kategori yaitu sangat rendah, rendah, sedang, tinggi, dan sangat tinggi.

Pada Lampiran 1 menampilkan pembagian wilayah Provinsi Jawa Timur dengan keterangan warna yang berbeda di setiap Kabupaten/Kota, sedangkan pada lampiran 2 menampilkan gambar peta tematik dari setiap variabel penelitian. Peta tematik pada Lampiran 2 menunjukkan bahwa warna lokasi semakin gelap mengidentifikasikan penyebaran jumlah kasus semakin tinggi.

- Kabupaten/kota yang masuk dalam kategori jumlah kasus pneumonia balita sangat tinggi adalah Kabupaten Gresik dan Sidoarjo (Gambar 2(a)).

- Kategori jumlah balita yang mendapat ASI eksklusif sangat rendah ada pada Kabupaten Lamongan, Kota Probolinggo, Kota Malang, Kota Madiun, Kabupaten Lumajang, Kota Blitar, Kota Mojokerto, Kota Pasuruan, Kota Kediri, dan Kota Batu (Gambar 2(b)).

- Kabupaten/kota yang masuk dalam kategori jumlah balita yang mendapat imunisasi dasar lengkap sangat rendah adalah Kabupaten Probolinggo, Kota Mojokerto, Kota Blitar, Kabupaten Kediri, Kota Madiun, Kota Batu, Kota Pasuruan, Kabupaten Malang, Kota Probolinggo, Kota Kediri, dan Kabupaten Pacitan (Gambar 2(c)).

- Kabupaten/kota yang masuk dalam kategori jumlah balita yang mendapatkan pelayanan kesehatan sangat tinggi adalah Kabupaten Sidoarjo, Kabupaten Jember, Kabupaten Malang, dan Kabupaten Surabaya (Gambar 2(d)).

- Kabupaten/kota yang masuk dalam kategori jumlah rumah tangga ber-PHBS sangat rendah adalah Kota Batu, Kabupaten Blitar, Kabupaten Pacitan, Kota Blitar, Kota Pasuruan, Kabupaten Malang, Kota Mojokerto, Kabupaten Sumenep, Kabupaten Kediri, Kota Blitar, Kabupaten Blitar, Kabupaten Situbondo, Kota Lumajang, Kota Kediri, dan Kabupaten Sampang (Gambar 2(e)).

- Kabupaten/kota yang masuk dalam kategori jumlah penduduk miskin sangat tinggi adalah Kabupaten Sampang, Kabupaten Probolinggo, Kabupaten Jember, dan Kabupaten Malang (Gambar 2(f)). 


\section{Estimasi Model Regresi Linier dan Uji Asumsi Analisis Regresi Linier}

Estimasi parameter model regresi linier dari penelitian ini adalah sebagai berikut:

Tabel 1. Estimasi Parameter Model Regresi

\begin{tabular}{|l|l|l|c|c|}
\hline & $\begin{array}{l}\text { Estimasi } \\
\text { Parameter }\end{array}$ & $\begin{array}{l}\text { Standar } \\
\text { Eror }\end{array}$ & $t_{\text {hitung }}$ & $P_{\text {value }}$ \\
\hline$\beta_{0}$ & 361,032509 & 438,09472 & 0,824 & 0,4160 \\
\hline$\beta_{1}$ & 0,032430 & 0,046397 & 0,699 & 0,4896 \\
\hline$\beta_{2}$ & 0,084991 & 0,032475 & 2,617 & 0,0134 \\
\hline$\beta_{3}$ & 0,020332 & 0,009613 & 2,115 & 0,0423 \\
\hline$\beta_{4}$ & 0,002648 & 0,003903 & 0,679 & 0,5023 \\
\hline$\beta_{5}$ & $-0,004027$ & 0,004147 & $-0,971$ & 0,3388 \\
\hline \multicolumn{5}{|c|}{$R^{2}=59,07 \%$} \\
\hline
\end{tabular}

Sumber: data diolah, 2019

Estimasi model regresi linier pada Tabel 1 berdasarkan pada variabel $X$ yang signifikan berpengaruh, yaitu variabel $\mathrm{X}$ yang mempunyai nilai $p$ lebih kecil dari $\alpha=0,05$. Estimasi model regresi dapat dituliskan sebagai berikut:

$$
\begin{aligned}
\widehat{Y}_{i}=361,032509 & +0,084991 X_{2, i} \\
& +0,020332 X_{3, i} .
\end{aligned}
$$

Hasil pengujian asumsi analisis regresi linier pada Persamaan 14, dengan menggunakan software $R$ diperoleh sebagai berikut:

\begin{tabular}{|c|c|c|}
\hline Hipotesis Uji & Statistik Uji & Keputusan \\
\hline $\begin{array}{l}H_{0}=\text { Sisaan } \\
\text { mengikuti } \\
\text { sebaran normal } \\
H_{1}=\text { sisaan } \\
\text { tidak mengikuti } \\
\text { sebaran normal }\end{array}$ & $\begin{array}{l}\chi^{2}=5,866 \\
d f=2 \\
p- \\
\text { value }=0,05324 \\
\chi_{(0.05) 3}^{2}=5,991\end{array}$ & $\begin{array}{l}H_{0} \text { diterima. } \\
\text { Hal ini berarti } \\
\text { sisaan pada } \\
\text { model } \\
\text { mengikuti } \\
\text { sebaran } \\
\text { normal. }\end{array}$ \\
\hline $\begin{array}{l}H_{0}=\text { tidak } \\
\text { terdapat } \\
\text { autokorelasi } \\
H_{1}=\text { terdapat } \\
\text { autokorelasi }\end{array}$ & $\begin{aligned} \mathrm{DW} & =1,6286 \\
\mathrm{dL} & =1,2042 \\
\mathrm{dU} & =1,7916 \\
d L & <D W<d U\end{aligned}$ & $\begin{array}{l}\text { Pengujian } \\
\text { tidak } \\
\text { meyakinkan. } \\
\text { Ada indikasi } \\
\text { bahwa } \\
\text { terdapat } \\
\text { autokorelasi. }\end{array}$ \\
\hline $\begin{array}{l}H_{0}=\text { ragam } \\
\text { homogen } \\
H_{1}=\text { ragam } \\
\text { tidak homogen }\end{array}$ & $\begin{array}{l}B P=14,241 \\
d f=5 \\
p-v a l u e= \\
0,01412 \\
\chi_{(0.1) 5}^{2}=11,070\end{array}$ & $\begin{array}{l}H_{0} \text { ditolak. } \\
\text { Hal ini berarti } \\
\text { ragam pada } \\
\text { model tidak } \\
\text { homogen. }\end{array}$ \\
\hline
\end{tabular}

Tabel 2. Uji Asumsi Analisis Regresi Linier

Sumber: data diolah, 2019

Tabel 3. Uji Multikolinieritas

\begin{tabular}{|c|l|l|}
\hline Variabel & Nilai VIF & Keputusan \\
\hline$x_{1}$ & 2,232909 & \multirow{5}{*}{ Tidak terdapat } \\
\cline { 1 - 2 }$x_{2}$ & 1,966625 & \multirow{2}{*}{ multikolinieritas } \\
\hline$x_{3}$ & 2,904407 & \\
\hline$x_{4}$ & 1,538612 & \\
\hline$x_{5}$ & 2,216688 & \\
\hline
\end{tabular}

Sumber: data diolah, 2019
Tabel 3 menunjukkan bahwa tidak terdapat multikolinieritas pada model karena nilai VIF dari masing-masing variabel kurang dari lima. Pada Tabel 2 terlihat bahwa masih terdapat pelanggaran asumsi dari uji asumsi analisis regresi linier yang dilakukan. Pada uji homoskedastisitas hasil yang diperoleh adalah ragam tidak homogen dan pada uji autokorelasi hasil yang diperoleh tidak meyakinkan, sehingga ada indikasi bahwa terdapat autokorelasi pada model. Oleh karena itu model regresi linier pada Persamaan 14 kurang baik untuk digunakan. Karena model yang diperoleh kurang baik, terdapat indikasi/kemungkinan adanya pengaruh spaisal pada data yang dianalisis. Untuk mengetahui hal tersebut, analisis dilanjutkan dengan uji kebergantungan spasial guna melihat ada tidaknya pengaruh spasial pada data yang digunakan.

\section{Uji Kebergantungan Spasial}

Kebergantungan spasial pada data dapat diketahui dengan melakukan uji Lagrange Multiplier. Hasil uji diperoleh sebagai berikut:

\begin{tabular}{|c|c|c|}
\hline Hipotesis & Nilai Statisti Uji & Keputusan \\
\hline $\begin{array}{l}H_{0}: \phi=0 \\
H_{1}: \phi \neq 0\end{array}$ & $\begin{array}{l}L M_{\text {lag }}=0,1663 \\
\chi_{(0.1) 5}^{2}=3,841 \\
p-\text { value }= \\
0,68342\end{array}$ & $\begin{array}{l}\mathrm{H}_{0} \text { diterima. } \\
\text { Tidak terdapat } \\
\text { kebergantungan } \\
\text { spasial pada } \\
\text { variabel } \\
\text { dependen. }\end{array}$ \\
\hline $\begin{array}{l}H_{0}: \theta=0 \\
H_{1}: \theta \neq 0\end{array}$ & $\begin{array}{l}L M_{\text {err }}=1,4114 \\
\chi_{(0.1) 5}^{2}=3,841 \\
p-\text { value }= \\
0,23483\end{array}$ & $\begin{array}{l}H_{0} \text { diterima. } \\
\text { Tidak terdapat } \\
\text { kebergantungan } \\
\text { spasial pada } \\
\text { sisaan. }\end{array}$ \\
\hline $\begin{array}{l}H_{0}: \phi=0 \\
\text { dan } \theta=0 \\
H_{1}: \phi \neq 0 \\
\text { dan }: \\
\theta \neq 0\end{array}$ & $\begin{array}{l}L M_{\text {lag,err }}=6,796 \\
\chi_{(0.1) 5}^{2}=5,991 \\
p-\text { value }= \\
0,03344\end{array}$ & $\begin{array}{l}H_{0} \text { ditolak. } \\
\text { Terdapat } \\
\text { kebergantungan } \\
\text { spasial pada } \\
\text { variabel } \\
\text { dependen dan } \\
\text { sisaan. }\end{array}$ \\
\hline
\end{tabular}

Tabel 4. Uji Lagrange Multiplier

Sumber: data diolah, 2019

Hasil uji Lagrange Multiplier pada Tabel 4 menunjukkan bahwa terdapat kebergantungan spasial pada variabel dependen dan sisaan sehingga analisis dilanjutkan dengan model analisis regresi spatial autoregressive moving average (SARMA).

\section{Fungsi Autokorelasi Spasial}

Untuk mengidentifikasi model yang tepat dalam pendugaan model SARMA digunakan 
fungsi autokorelasi (ACF) seperti halnya pada model ARMA. Fungsi autokorelasi spasial menunjukkan kekuatan autokorelasi spasial dari unit spasial pada tingkat tertentu.

Tabel 5. Uji Signifikansi ACF

\begin{tabular}{|l|c|c|}
\hline & Koefisien & Selang (Interval) \\
\hline \multicolumn{3}{|c|}{ Autokorelasi Pada Variabel Dependen } \\
\hline 1 & 0,3614708 & $(0,08731657 ; 0,635625)$ \\
\hline 2 & $-0,02107975$ & $(-0,295234 ; 0,2530744)$ \\
\hline 3 & $-0,09034016$ & $(-0,3644944 ; 0,183814)$ \\
\hline 4 & $-0,09292131$ & $(-0,3670755 ; 0,181233)$ \\
\hline 5 & $-0,05388414$ & $(-0,3280383 ; 0,220270)$ \\
\hline 6 & $-0,06880983$ & $(-0,342964 ; 0,2053444)$ \\
\hline 7 & $-0,05341103$ & $(-0,327565 ; 0,2207432)$ \\
\hline Autokorelasi Pada Sisaan \\
\hline 1 & $-0,1660659$ & $(-0,440220 ; 0,1080883)$ \\
\hline 2 & 0,0127776 & $(-0,261377 ; 0,2869318)$ \\
\hline 3 & $-0,06905472$ & $(-0,343209 ; 0,2050995)$ \\
\hline 4 & $-0,1230305$ & $(-0,97185 ; 0,1511237)$ \\
\hline 5 & 0,02602153 & $(-0,248133 ; 0,3001757)$ \\
\hline 6 & 0,01401625 & $(-0,260138 ; 0,2881705)$ \\
\hline 7 & 0,00316206 & $(-0,270992 ; 0,2773163)$ \\
\hline
\end{tabular}

Sumber: data diolah, 2019

Hasil Uji signifikansi koefisien autokorelasi pada Tabel 5 menunjukkan bahwa koefisien autokorelasi signifikan pada fungsi autokorelasi variabel dependen order (tingkat) pertama karena interval pada koefisien autokorelasi tersebut tidak memuat nilai 0 , sehingga pemodelan regresi SARMA yang akan dilakukan adalah pemodelan regresi SARMA pada tingkat pertama.

\section{Pemodelan Regresi Spatial Autoregressive Moving Average (SARMA)}

Model regresi SARMA pada tingkat pertama terdiri dari SARMA $(1,0)$, SARMA $(0,1)$, dan SARMA $(1,1)$. Penduga parameter dari masing-masing model regresi SARMA tersebut adalah sebagai berikut:

Tabel 6. Penduga Parameter Regresi SARMA

\begin{tabular}{|c|r|c|r|}
\hline \multirow{2}{*}{} & \multicolumn{3}{|c|}{ Penduga Parameter } \\
\cline { 2 - 4 } & $\begin{array}{l}\text { SARMA } \\
(1,0)\end{array}$ & $\begin{array}{l}\text { SARMA } \\
(0,1)\end{array}$ & \multicolumn{1}{l|}{$\begin{array}{l}\text { SARMA } \\
(1,1)\end{array}$} \\
\hline$\beta_{0}$ & 240,69631 & 252,18542 & $-144,89$ \\
\hline$\beta_{1}$ & 0,0304212 & 0,0421493 & $-0,02097$ \\
\hline$\beta_{2}$ & 0,0819201 & 0,0920442 & 0,09932 \\
\hline$\beta_{3}$ & 0,0194716 & 0,0273765 & 0,02247 \\
\hline$\beta_{4}$ & 0,0024479 & 0,0041200 & 0,00122 \\
\hline$\beta_{5}$ & $-0,0034122$ & $-0,0075780$ & $-0,00472$ \\
\hline$\phi_{1}$ & 0,057329 & & 0,08332 \\
\hline$\theta_{1}$ & & $-0,38079$ & $-0,63415$ \\
\hline$R^{2}$ & $59,27 \%$ & $62,99 \%$ & $73,17 \%$ \\
\hline
\end{tabular}

Sumber: data diolah, 2019
Untuk menentukan model terbaik, dilakukan dengan melihat nilai Akaike's Information Criterion (AIC) pada masingmasing model. Nilai AIC dari masing-masing model adalah sebagai berikut.

Tabel 7. Nilai AIC Model Regresi SARMA

\begin{tabular}{|l|c|}
\hline & Nilai AIC \\
\hline SARMA $(1,0)$ & 660,45 \\
\hline SARMA $(0,1)$ & 658,36 \\
\hline SARMA $(1,1)$ & 649,55 \\
\hline
\end{tabular}

Sumber: data diolah, 2019

Model terbaik dengan kriteria AIC yang dipilih adalah model SARMA(1,1) karena memiliki nilai AIC terkecil.

Pengujian signifikansi parameter model regresi SARMA $(1,1)$ dilakukan dengan uji Wald. Hasil yang diperoleh adalah sebagai berikut:

Tabel 8. Uji Wald Model Regresi SARMA(1,1)

\begin{tabular}{|c|r|r|}
\hline Parameter & \multicolumn{1}{|l|}{ Wald } & $p$-value \\
\hline$\beta_{1}$ & $-0,56557$ & 0,57169 \\
\hline$\beta_{2}$ & 4,39936 & 0,00001 \\
\hline$\beta_{3}$ & 3,18990 & 0,00142 \\
\hline$\beta_{4}$ & 0,51871 & 0,60398 \\
\hline$\beta_{5}$ & $-1,87749$ & 0,06045 \\
\hline$\phi$ & 3,70011 & 0,00022 \\
\hline$\theta$ & $-2,96207$ & 0,00717 \\
\hline
\end{tabular}

Sumber: data diolah, 2019

Tabel 8 menunukkan bahwa variabel $X_{2}$ dan $X_{3}$ berpengaruh secara signifikan terhadap variabel Y. Begitu juga dengan variabel Y serta sisaan dari suatu daerah akan berpengaruh secara signifikan terhadap daerah yang dikelilinginya.

Estimasi dari model regresi SARMA $(1,1)$ dapat dituliskan sebagai berikut:

$$
\begin{aligned}
\hat{Y}_{i}=-144.89+ & 0.08332 \sum_{j=1}^{n} w_{i, j} Y_{j} \\
& +0.09932 X_{2, i}+0.02247 X_{3, i} \\
& -0.63415 \sum_{j=1}^{n} w_{i, j} \varepsilon_{j} .
\end{aligned}
$$

Model SARMA $(1,1)$ yang dimiliki oleh setiap kabupaten/kota di Provinsi Jawa Timur berbeda. Hal ini bergantung pada nilai pembobot spasial dari kabupaten/kota yang saling berhubungan. Salah satunya adalah model SARMA (1.1) dari Kabupaten Pacitan yaitu: 


$$
\begin{array}{rl}
\hat{Y}_{\text {Pacitan }}=-14 & 4,89+0,08332\left(0,5 Y_{\text {Ponorogo }}\right. \\
& \left.+0,5 Y_{\text {Trenggalek }}\right) \\
& +0,09932 X_{2, \text { Pacitan }} \\
& +0,02247 X_{3, \text { Pacitan }} \\
& -0,63415\left(0,5 \varepsilon_{\text {Ponorogo }}\right. \\
& \left.+0,5 \varepsilon_{\text {Trenggalek }}\right)
\end{array}
$$

\section{Interpretasi Model Regresi SARMA}

Model SARMA $(1,1)$ pada Persamaan 15 dapat diinterpretasikan sebagai berikut:

1. Koefisisien $\hat{\phi}_{1}=0,08332$ bermakna jika suatu daerah dikelilingi $n$ daerah lain, maka pengaruh dari masing-masing daerah yang mengelilinginya dapat diukur sebesar 0,08332 dikali jumlah kasus pneumonia balita pada daerah di sekitarnya.

2. Koefisien $\hat{\theta}_{1}=-0,63415$ bermakna jika suatu daerah dikelilingi $n$ daerah lain, maka sisaan dari daerah tersebut dikoreksi oleh sisaan dari daerah tetangganya sebesar $-0,63415$ dikali nilai pembobot spasial pada daerah disekitarnya.

3. Koefisien $\hat{\beta}_{0}=-144,89$ bermakna jika ada variabel $x$ yang bernilai 0 , maka jumlah kasus pneumonia balita di setiap kabupaten/kota akan menurun sebesar 144,89 . Jika tidak ada faktor yang bernilai 0 , maka nilai $\hat{\beta}_{0}=-144,89$ tidak bermakna.

4. Koefisien $\hat{\beta}_{2}=0,09932$ bermakna jika jumlah balita yang mendapat imunisasi dasar lengkap di suatu kabupaten/kota meningkat satu satuan maka akan meningkatkan jumlah kasus pneumonia balita di kabupaten/kota tersebut sebesar 0,09932 apabila faktor-faktor lainnya dianggap konstan. Peningkatan jumlah kasus pneumonia yang harusnya menurun dengan bertambahnya jumlah balita yang mendapat imunisasi dasar lengkap diindikasi disebabkan oleh imunisasi yang dilakukan tidak sesuai untuk penyakit pneumonia. Menurut dr. Nastiti Kaswandani, Sp.A (K) dalam yang dapat mencegah pneumonia adalah vaksin Pneumokokus dan $\mathrm{HiB}$ yang belum termasuk dalam program imunisasi dasar lengkap yang dilakukan oleh pemerintah. Vaksin Pneumokokus dan HiB akan menurunkan $50 \%$ angka kematian balita akibat pneumonia.

5. Koefisien $\hat{\beta}_{3}=0,02247$ bermakna jika jumlah balita yang mendapatkan pelayanan kesehatan di suatu kabupaten/kota meningkat satu satuan maka akan meningkatkan jumlah kasus pneumonia balita di kabupaten/kota tersebut tersebut sebesar 0,02247 apabila faktor-faktor lainnya dianggap konstan. Hal ini sesuai karena semakin banyak balita yang mendapat pelayanan kesehatan berarti semakin banyak balita yang dirawat karena sakit dan ada kemungkinan bahwa penyakit adalah pneumonia.

6. Model SARMA $(1,1)$ memiliki nilai $R^{2}$ sebesar 73,17\%. Hal ini berarti faktorfaktor yang berpengaruh dalam penelitian ini mampu menjelaskan jumlah kasus pneumonia balita di Provinsi Jawa Timur sebesar 73,17\%, sedangkan sisanya dijelskan oleh faktor lain diluar model.

\section{KESIMPULAN DAN SARAN}

\section{Kesimpulan}

1. Pada pemodelan jumlah kasus pneumonia di setiap kabupaten/kota di Provinsi Jawa Timur diperoleh bahwa ada kebergantungan spasial pada variabel dependen dan sisaan dari model pada tingkat pertama, sehingga estimasi model regresi linier dengan koefisien determinasi $\left(R^{2}\right)$ sebesar 59,07\% kurang baik untuk memodelkan jumlah kasus pneumonia tersebut. Oleh karena itu model yang dipilih adalah regresi SARMA $(1,1)$ dengan AIC sebesar 649,55 dan $R^{2}$ sebesar $73,17 \%$.

2. Faktor yang berpengaruh secara signifikan terhadap jumlah kasus pneumonia balita pada setiap kabupaten/kota di Provinsi Jawa Timur adalah jumlah balita yang mendapat imunisasi dasar lengkap dan jumlah balita yang mendapat pelayanan kesehatan

\section{Saran}

1. Niai $R^{2}$ yang diperoleh dari model belum cukup tinggi. Disarankan untuk menambahkan variabel independen yang diduga signifikan serta mempertimbangkan kelinieran dari model.

2. Dalam penelitian selanjutnya disarankan untuk menggunakan data balita yang 
mendapat vaksin pneumokokus dan $\mathrm{HiB}$ agar faktor yang berpengaruh terhadap jumlah kasus pneumonia lebih akurat lagi.

\section{DAFTAR PUSTAKA}

Anselin, L., 1988. Spatial Econometrics: Methods and Models. Netherlands: Kluwer Academic Publishers.

Dinas Kesehatan Provinsi Jawa Timur. 2018. Profil Kesehatan Provinsi Jawa Timur Tahun 2017. Jawa Timur: Dinkes Provinsi Jawa Timur.

Gujarati, D. N. \& Porter, D. C., 2009. Basic Econometrics. Fifth Edition ed. New York: McGraw-Hill/Irwin,.

Huang, J. S., 1984. The Autoregressive Moving Average Model for Spatial Analysis. Austral. J. Statist, Volume 26(2), pp. 169178.

Ikatan Dokter Anak Indonesia. 2017. Sekilas Vaksin Pneumokokus. http://www.idai. or.id/artikel/klinik/imunisasi/sekilasvaksin-pneumokokus. Diakses: 6 Mei 2019.

Kruk, R. v. d., 2002. A General Spatial ARMA Model: Theory and Application (online). https://core.ac.uk/download/pdf/7036080.p df. Diakses: 8 November 2018

Kutner, M. H., Nachtsheim, C. J., Neter, J. \& LI, W., 2005. Applied Linear Statistical Model. Fifth Edition ed. New York: McGraw-Hill/Irwin.

Qauliyah, Asta. 2010. Referat Kedokteran: Etiologi dan Patofisiologi Penyakit Pneumonia.https://www.astaqauliyah.com/ blog/read/1924/referat-kedokteran-etiologidan-patofisiologi-penyakit-

pneumonia.html. Diakses 7 Januari 2019. 


\section{Lampiran 1. Peta Wilayah Provinsi Jawa Timur}

\section{Peta Provinsi Jawa Timur}

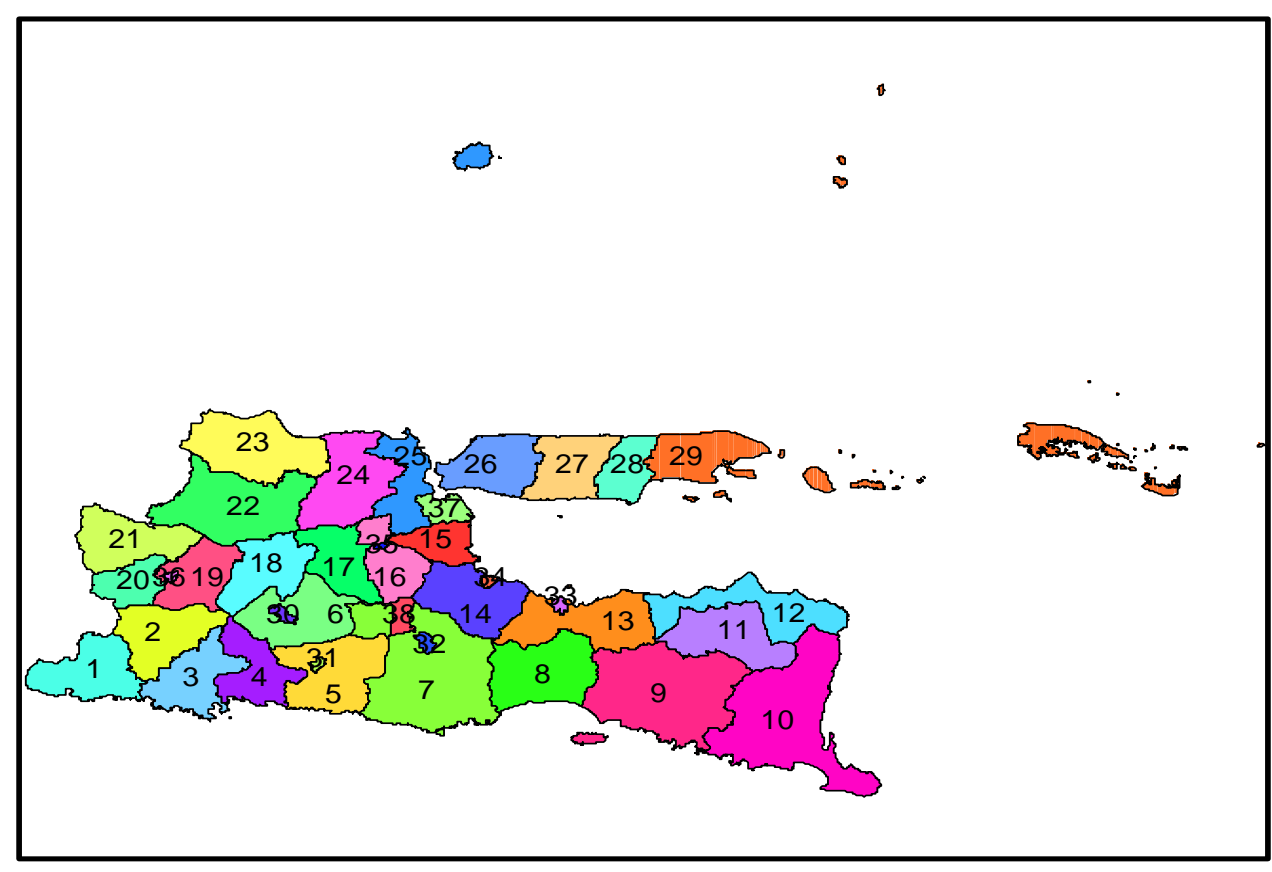

Provinsi Jawa Timu $r$

\begin{tabular}{|l}
\hline 1. Pacitan \\
2. Ponorogo \\
3. Trenggalek \\
4. Tulungagung \\
5. B litar \\
6. Kediri \\
7. Malang \\
8. Lumajang \\
9. Jember \\
10. Banyuwangi \\
11. Bondowoso \\
12. Situbondo \\
13. Probolinggo \\
14. Pasuruan \\
15. Sidoarjo \\
16. Mojokerto \\
\hline \hline 17. Jombang \\
18. Nganjuk \\
19. Madiun \\
20. Magetan \\
21. Ngawi \\
22. Bojonegoro \\
23. Tuban \\
24. Lamongan \\
25. Gresik \\
26. Bangkalan \\
27. Sampang \\
28. Pamakasan \\
29. Sumenep \\
30. Kota_kediri \\
31. Kota_blitar \\
32. Kota_malang \\
33. Kota_probolinggo \\
34. Kota_pasuruan \\
35. Kota_mojokerto \\
36. Kota_madiun \\
37. Kota_surabaya \\
38. Kota_batu \\
\end{tabular}




\section{Lampiran 2. Peta Tematik Variabel Penelitian}

\section{Peta Penyebaran Jumlah Kasus} Pneumonia Balita di Provinsi Jawa Timur

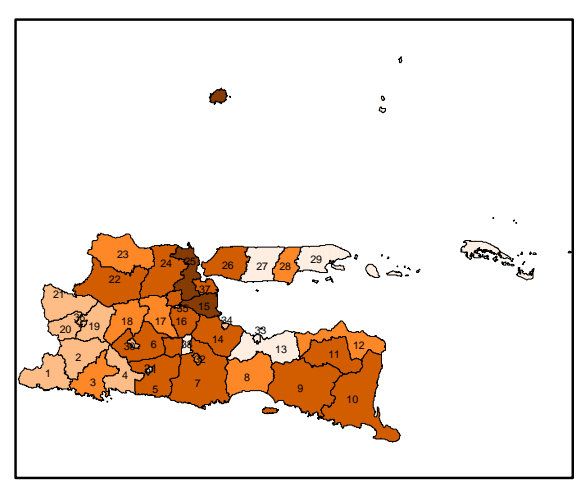
$108-669$ $1467-2378$ $1467-2378$ $2379-4736$
$4737-8747$<smiles>CC(C)(C)C(N)(N)I</smiles>

(a)

Peta Penyebaran Jumlah Balita yang Mendapat Pelayanan Kesehatan di Provinsi Jawa Timur

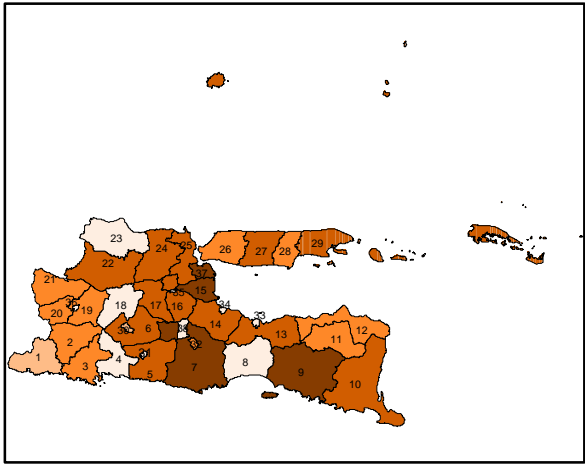

(d)

N $^{N}$
Peta Penyebaran Jumlah Balita yang Mendapat ASI Eksklusif di Provinsi Jawa Timur

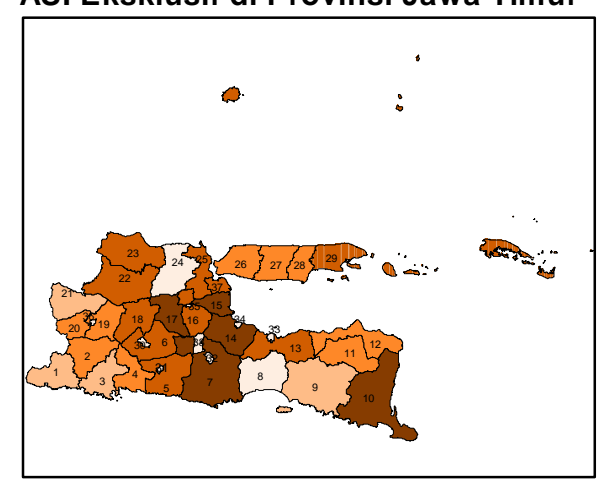

(b)

Peta Penyebaran Jumlah Rumah Tangga ber-PHBS di Provinsi Jawa Timur
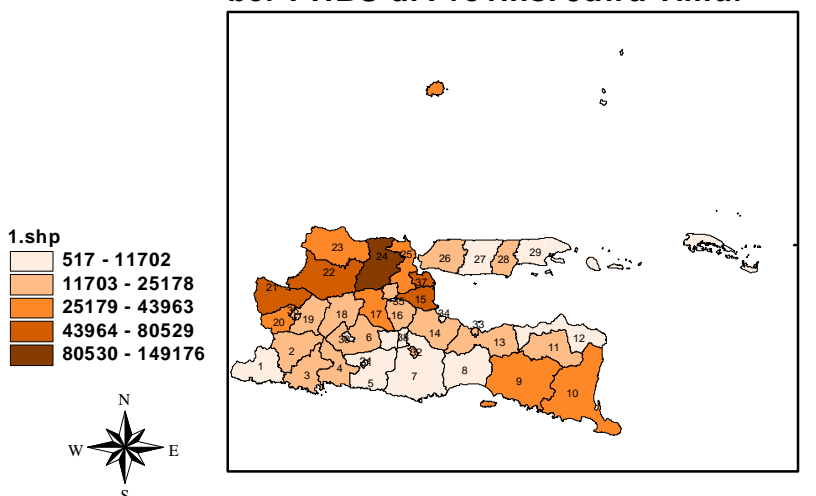

(e)
Peta Penyebaran Jumlah Balita yang Mendapat imunisasi Dasar Lengkap di Provinsi Jawa Timur
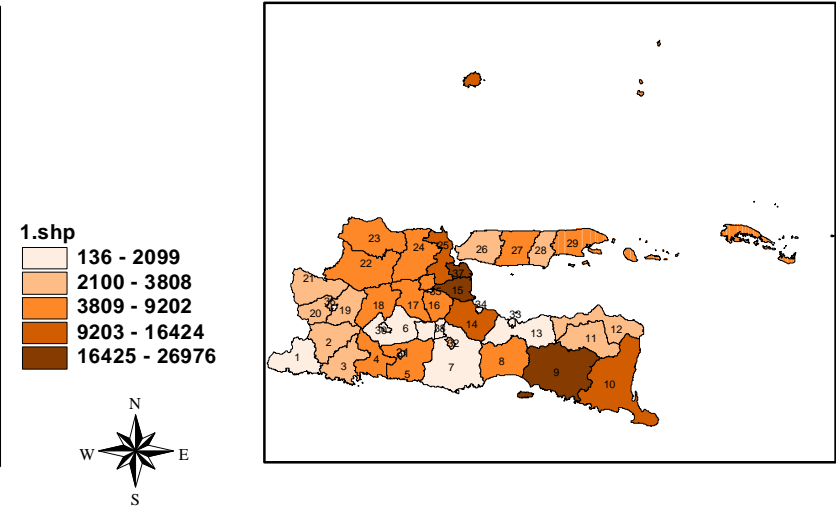

$1592-5681$ $5682-12159$ $28375-23826$
1830

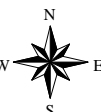

(c)

Peta Penyebaran Jumlah Penduduk Miskin di Provinsi Jawa Timur

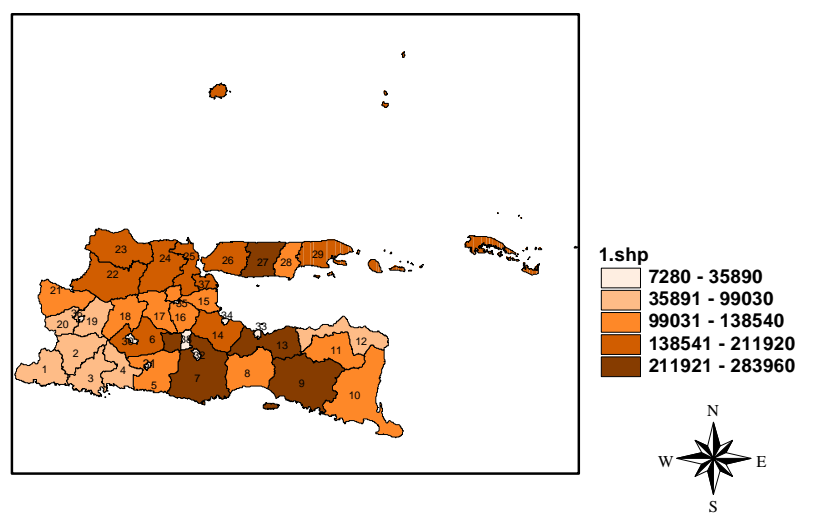

